\title{
Oncholaimus tripapillatus sp. nov., a New Free-Living Marine Nematode of the Genus Oncholaimus Dujardin, 1845 (Nematoda: Enoplida: Oncholaimidae) from the Subtidal Sediment of Dokdo Island, East Sea, Korea, with a New Record of O. qingdaoensis Zhang \& Platt, 1983
}

\author{
Hyojin Lee (D), Heegab Lee and Hyunsoo Rho *(D)
}

check for updates

Citation: Lee, H.; Lee, H.; Rho, H. Oncholaimus tripapillatus sp. nov., a New Free-Living Marine Nematode of the Genus Oncholaimus Dujardin, 1845 (Nematoda: Enoplida:

Oncholaimidae) from the Subtidal Sediment of Dokdo Island, East Sea, Korea, with a New Record of $O$. qingdaoensis Zhang \& Platt, 1983. J. Mar. Sci. Eng. 2021, 9, 1334. https:// doi.org/10.3390/jmse9121334

Academic Editor: Francesco Tiralongo and Anna Di Cosmo

Received: 28 October 2021

Accepted: 25 November 2021

Published: 27 November 2021

Publisher's Note: MDPI stays neutral with regard to jurisdictional claims in published maps and institutional affiliations.

Copyright: (c) 2021 by the authors. Licensee MDPI, Basel, Switzerland. This article is an open access article distributed under the terms and conditions of the Creative Commons Attribution (CC BY) license (https:// creativecommons.org/licenses/by/ $4.0 /)$.
East Sea Environment Research Center, Korea Institute of Ocean Science \& Technology (KIOST), Uljin 36315, Korea; hjlee086@kiost.ac.kr (H.L.); leehg@kiost.ac.kr (H.L.)

* Correspondence: hsrho@kiost.ac.kr; Tel.: +82-54-780-5345; Fax: +82-54-780-5349

Abstract: During a survey of the free-living marine nematodes of Korea, two species belonging to the genus Oncholaimus Dujardin, 1845 were discovered. A new species, Oncholaimus tripapillatus sp. nov. and a newly recorded species, Oncholaimus qingdaoensis Zhang \& Platt, 1983, are reported. Oncholaimus tripapillatus sp. nov. was collected from the washing of subtidal coarse sediments around Dokdo Island of the East Sea, Korea. Oncholaimus tripapillatus sp. nov. is characterized by a relatively long (4071-4435 $\mu \mathrm{m}$ in males and 4514-4661 $\mu \mathrm{m}$ in females) and slender body, a slightly constricted head region, relatively long cephalic setae $(10-12 \mu \mathrm{m})$, males having a precloacal sexual protuberance bearing two small cone-shaped supplementary spines, five pairs of long cloacal setae (three pairs of precloacal and two pairs of postcloacal setae in subventral position), and three remarkable papillae near the end of the tail, with two pairs of subventral setae. The Korean specimens of Oncholaimus qingdaoensis Zhang \& Platt, 1983 are almost identical to the Chinese specimens of the original description from the intertidal sand of Qingdao, China. However, the Korean specimens differ from the Chinese specimens in the longer body length in males (3379-3715 $\mu \mathrm{m}$ vs. $2380-2640 \mu \mathrm{m})$, the larger spicule length (47-52 $\mu \mathrm{m}$ vs. 34-36 $\mu \mathrm{m})$, and the presence of ventral tail papillae situated around 14-16 $\mu \mathrm{m}$ from the tail tip. Detailed morphological features and illustrations of two Oncholaimus species from Korea were obtained by differential interference contrast microscopy and scanning electron microscopy. A pictorial key to the species group with distinct tail papillae among the genus Oncholaimus is also provided.

Keywords: taxonomy; marine nematode; Oncholaimus; Dokdo; the East Sea; Korea

\section{Introduction}

The genus Oncholaimus Dujardin, 1845 is distinguished from the other genera of the family by the presence of the largest left ventrosublateral tooth, relatively short spicules, and monodelphic-prodelphic reproductive system in females [1]. The genus Oncholaimus shows worldwide distribution and occurs in various habitats, from littoral sediment to brackish water and deep-sea environments [2,3]. Thus far, about 120 nominated species of the genus Oncholaimus have been described across the world [4]. Of these, 24 species of the genus Oncholaimus have been described from the northwest Pacific Ocean as follows: 16 species (O. asiaticus (Belogurov et. al., 1980), O. compositus Belogurov et. al., 1980, O. eximius Belogurova, 1978, O. fucus (Smolyanko \& Belogurov, 1991), O. furugelmus (Belogurov, 1977), O. japonicus (Belogurov \& Belogurova, 1981), O. olium (Belogurov et. al., 1975), O. paracampylocercoides Smolyanko \& Belogurov, 1991, O. paraolium (Belogurov \& Fadeeva, 1980), O. paropisthonchus Belogurov \& Belogurova, 1978, O. ramosum (Smolyanko \& Belogurov, 1987), O. unicus (Belogurov \& Belogurova, 1978), O. urbanus (Belogurov et. al., 
1972), O. venustus (Belogurov et. al., 1972), O. vesicarius (Wieser, 1953), O. zinus Belogurov \& Belogurova, 1978) from Shikotan Island, Kuril Islands, and its adjacent Russian waters of the East Sea (Sea of Japan) [5-8]; two species (O. dujardinii de Man, 1876 and O. secundicollis Shimada et. al., 2009) from Wakayama and Hokkaido of Japan [9,10]; six species (O. minor Chen \& Guo, 2014, O. multisetosus Huang \& Zhang, 2006, O. qingdaoensis Zhang \& Platt, 1983, O. sinensis Zhang \& Platt, 1983, O. xiamenense Chen \& Guo, 2014, and O. zhangi Gao \& Huang, 2017) from the East China Sea and the Yellow Sea of China [11-13]. Of these, only one Oncholaimus species, O. secundicollis, has been reported from the rocky intertidal seagrass habitat on the eastern coast of Korea $[10,14]$.

During a continuous ecological investigation on the biodiversity of the free-living marine nematodes around Korean waters, we found two Oncholaimus species from the intertidal and subtidal sediments of the eastern, southern, and western coasts of Korea. The present paper deals with morphological descriptions, illustrations, and photomicrographs from differential interference contrast (DIC) microscopy and scanning electron microscopy. Moreover, we also provide a pictorial key and a comparison table of the diagnostic morphological characteristics of the species within the genus Oncholaimus with distinct tail papillae in the tail region.

\section{Materials and Methods}

\subsection{Sampling of Taxa}

The marine nematodes were obtained from the upper surface of the intertidal sediment from the southern and western coasts of Korea using a hand scoop, as well as by means of a Smith-McIntyre grab from the shallow subtidal benthic environment sediment of Dokdo Islands, located in the East Sea in the northwest Pacific Ocean.

\subsection{Sample Processing and Preparation of the Specimens}

The samples were filtered through a sieve with $67 \mu \mathrm{m}$ mesh in the field after rinsing with freshwater for less than $1 \mathrm{~min}$ for osmotic shock and then fixed in $5 \%$ formalin [15]. In the laboratory, the nematodes were sorted from the mixed meiobenthos under a LEICA 205 C stereomicroscope (Leica, Wetzlar, Germany). The nematodes were transferred to glycerol and mounted between two cover slips on an HS slide for morphological observations [16]. The specimens were measured, examined, and drawn using Nomarski differential interference contrast (DIC) microscopy with an Olympus BX53 microscope equipped with a drawing tube and an Olympus DP26 digital camera with the corresponding Olympus CellSens imaging software (Olympus, Tokyo, Japan). The specimens selected for scanning electron microscopy (SEM) were fixed in 5\% buffered formalin and then rinsed twice with distilled water to remove the buffered formalin. After rinsing for $5 \mathrm{~min}$ each, the specimens were freeze-dried in a cooling stage, mounted on an aluminum stub, sputter-coated with gold/palladium in a high-vacuum evaporator, and examined with an SEC SNE-3200M Desktop Mini SEM.

\subsection{Terminology and Abbreviations}

Measurements are in micrometers $(\mu \mathrm{m})$. The abbreviations used in the text are as follows: $a$, body length divided by maximum body diameter; $b$, body length divided by pharynx length; c, body length divided by tail length; V (\%), vulva distance from anterior end as percentage of total body length.

\section{Results}

\subsection{Description of Oncholaimus tripapillatus sp. nov.}

Class Enoplea Inglis, 1983

Order Enoplida Filipjev, 1929

Family Oncholaimidae Filipjev, 1916

Genus Oncholaimus Dujardin, 1845

Oncholaimus tripapillatus sp. nov. (Figures 1-4; Table 1) 

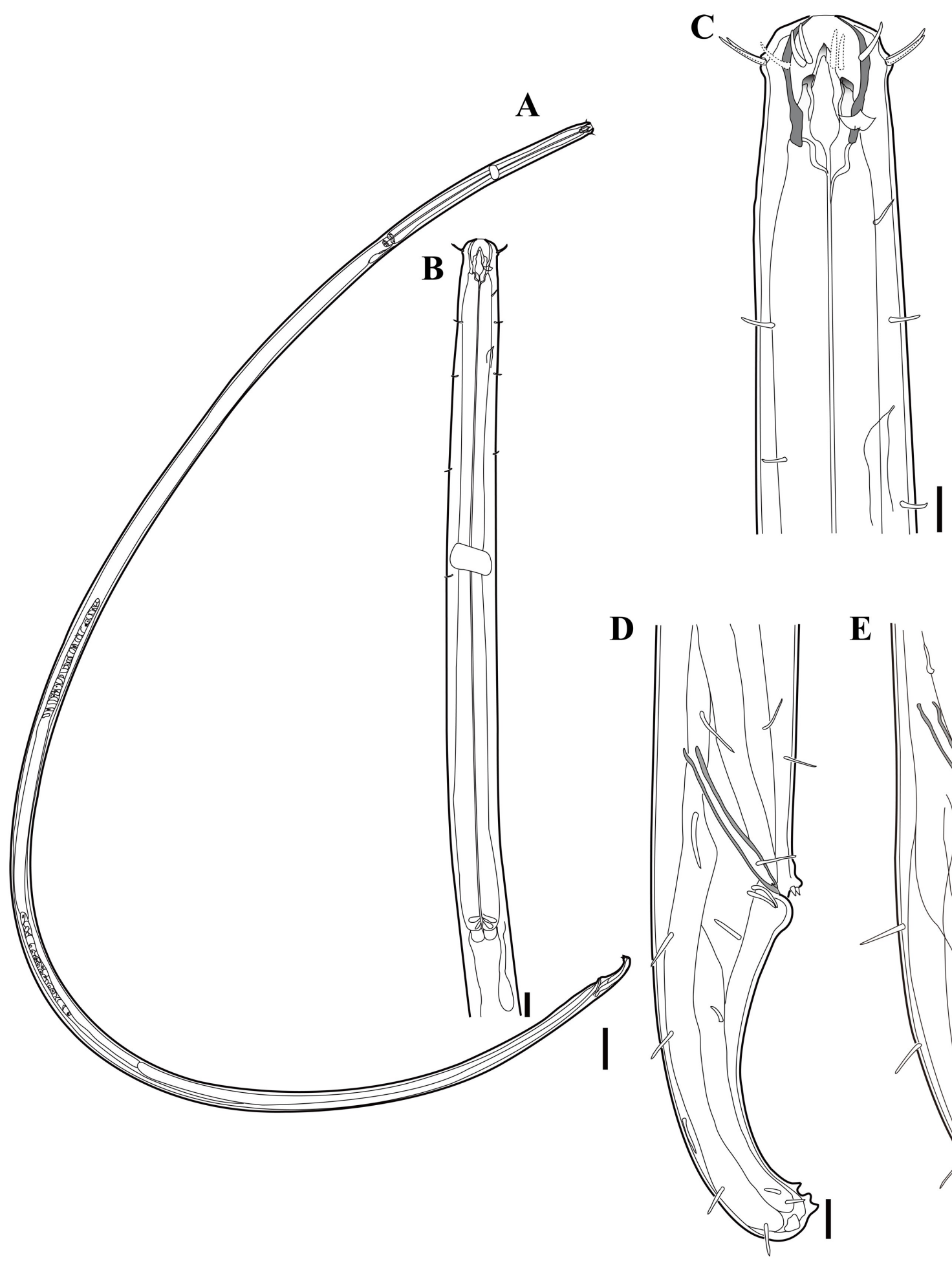

Figure 1. Oncholaimus tripapillatus sp. nov.-holotype male in lateral view: (A) habitus; (B) anterior region; (C) head region; (D) spicule and tail region; $(\mathbf{E})$ spicule and tail region in paratype (scale bars: $(\mathbf{A})=100 \mu \mathrm{m} ;(\mathbf{B})=20 \mu \mathrm{m} ;(\mathbf{C}-\mathbf{E})=10 \mu \mathrm{m})$. 


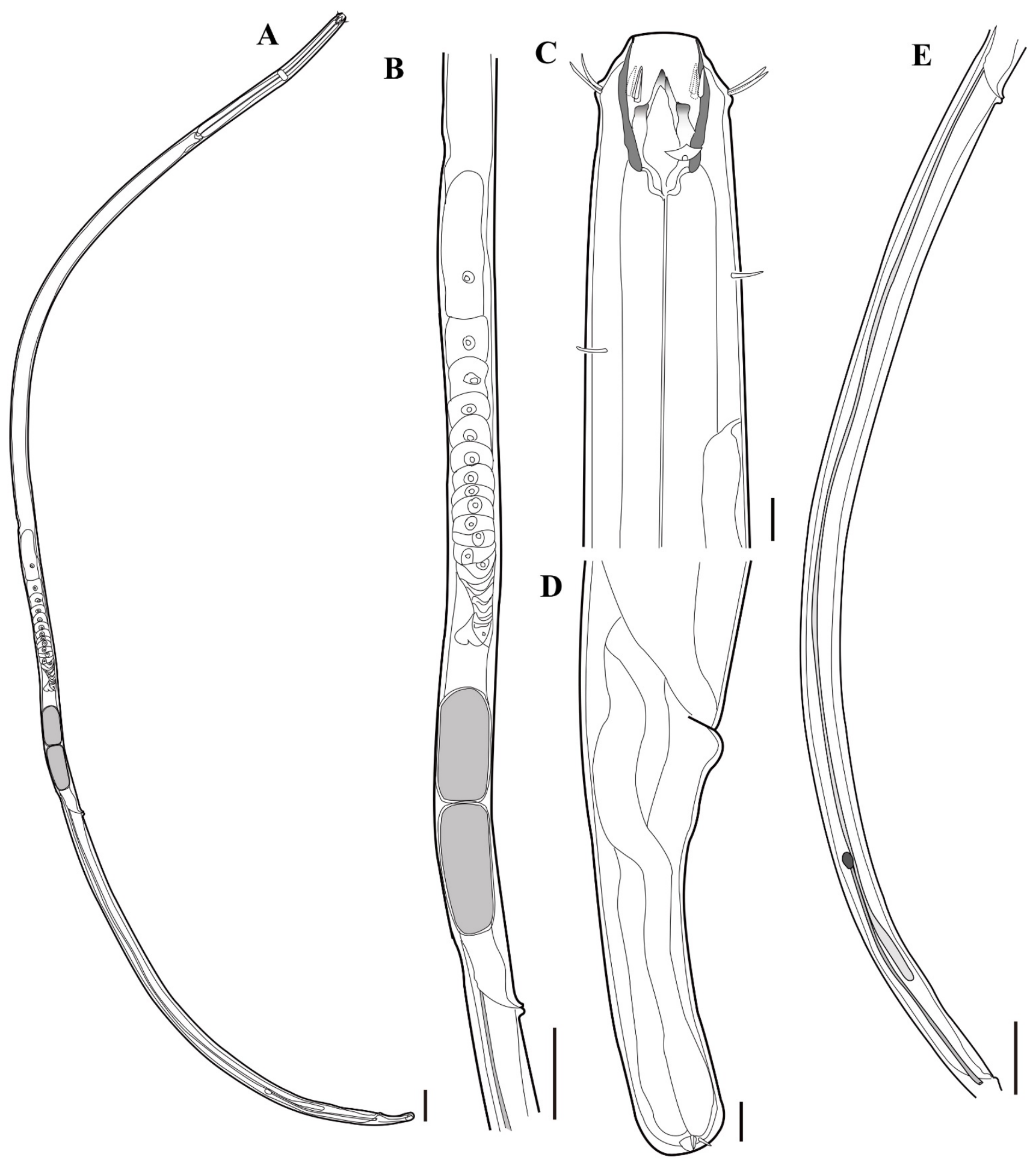

Figure 2. Oncholaimus tripapillatus sp. nov.-paratype female in lateral view: (A) habitus; (B) vulva region; (C) head region; (D) tail region; (E) female demanian system (scale bars: $(\mathbf{A}, \mathbf{E})=100 \mu \mathrm{m} ;(\mathbf{B})=50 \mu \mathrm{m} ;(\mathbf{C}, \mathbf{D})=10 \mu \mathrm{m})$. 

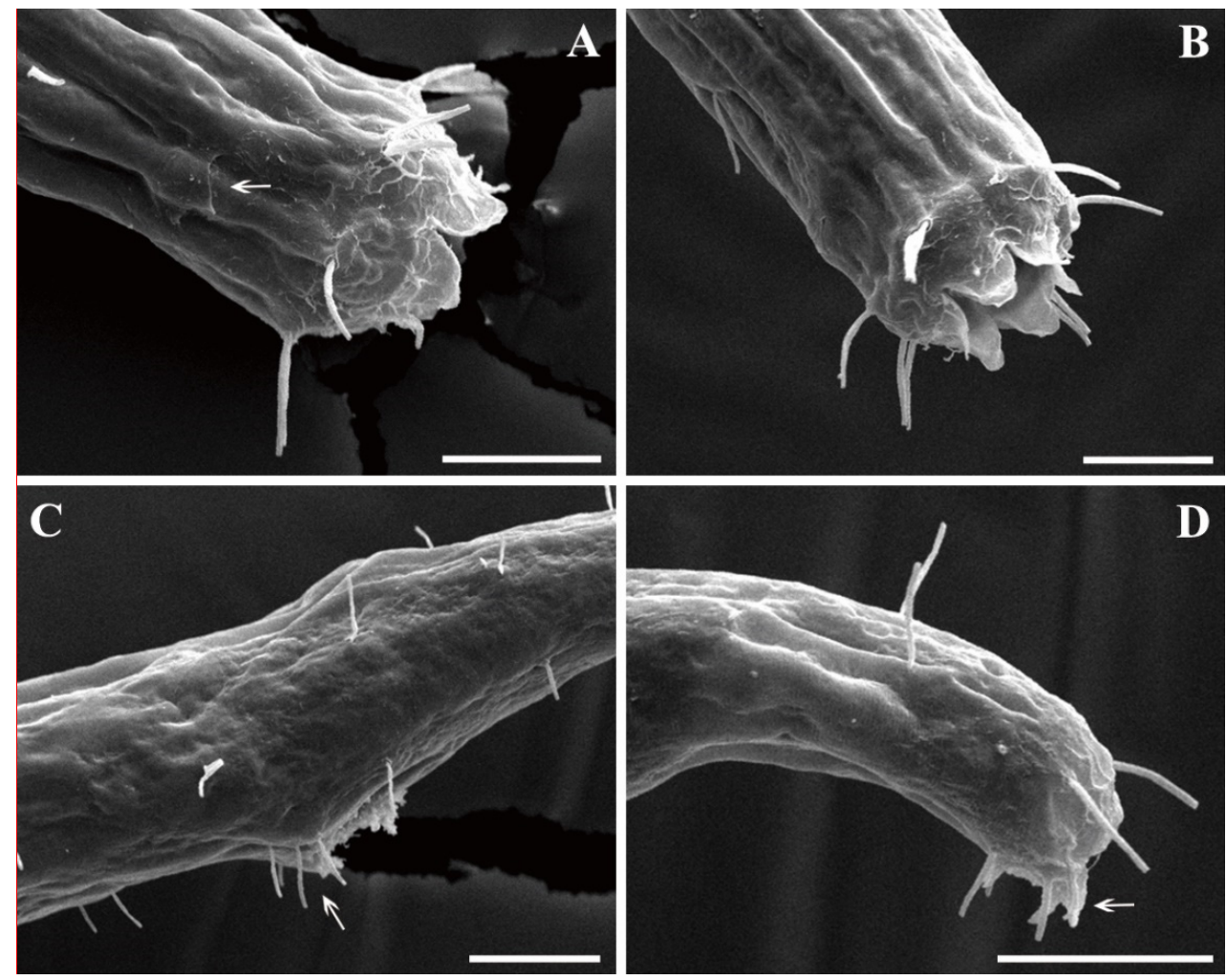

Figure 3. Oncholaimus tripapillatus sp. nov.-SEM photomicrographs of a male $(\mathbf{A}, \mathbf{C}, \mathbf{D})$ and a female (B): (A) head region showing amphideal fovea; (B) six low lips and cephalic setae region; (C) cloacal region showing precloacal sexual protuberance and precloacal setae (arrow); (D) tail region showing three papillae (arrow) and subventral setae (scale bars: $(\mathbf{A}-\mathbf{D})=15 \mu \mathrm{m})$.
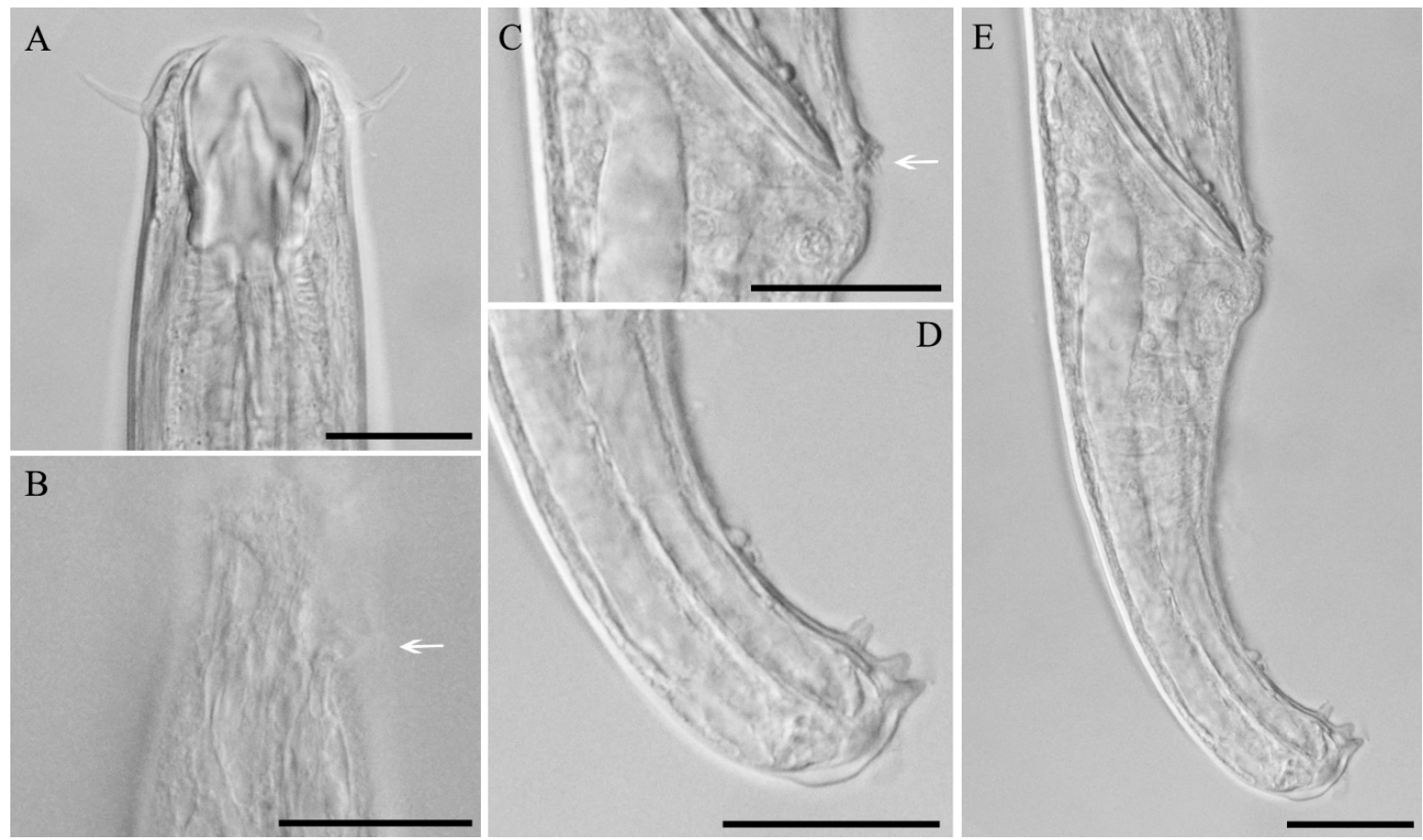

Figure 4. Oncholaimus tripapillatus sp. nov.-DIC photomicrographs, showing a lateral view of a male: (A) head region; (B) head region showing amphideal fovea (arrow); (C) cloacal region showing precloacal spines (arrow); (D) tail region showing three papillae; (E) spicules and tail region (scale bars: $(A-E)=20 \mu \mathrm{m})$. 
Table 1. Morphometrics of Oncholaimus tripapillatus sp. nov. (in $\mu \mathrm{m})$.

\begin{tabular}{|c|c|c|c|c|c|c|}
\hline \multirow{2}{*}{ Characters } & \multirow{2}{*}{$\begin{array}{c}\text { Holotype } \\
10^{7}\end{array}$} & \multicolumn{5}{|c|}{ Paratypes } \\
\hline & & $10^{\pi}$ & $20^{7}$ & 19 & $2 q$ & $3+$ \\
\hline Total body length & 4281 & 4435 & 4071 & 4514 & 4661 & 4520 \\
\hline $\mathrm{a}$ & 82 & 86 & 83 & 70 & 64 & 72 \\
\hline $\mathrm{b}$ & 8 & 8 & 8 & 7 & 8 & 8 \\
\hline c & 46 & 48 & 42 & 41 & 41 & 41 \\
\hline $\begin{array}{l}\text { Head diameter at the level of } \\
\text { cephalic setae }\end{array}$ & 30 & 30 & 30 & 31 & 32 & 30 \\
\hline Body diameter at the level of cardia & 42 & 42 & 43 & 52 & 54 & 46 \\
\hline Maximum body diameter & 52 & 51 & 49 & 65 & 73 & 63 \\
\hline Cephalic setae length & 10 & 11 & 12 & 11 & 11 & 11 \\
\hline Amphideal fovea diameter & 9 & 8 & 11 & 10 & 9 & 10 \\
\hline Amphideal fovea length & 5 & 6 & 7 & 6 & 6 & 5 \\
\hline Buccal cavity diameter & 19 & 20 & 20 & 20 & 21 & 22 \\
\hline Buccal cavity length & 29 & 31 & 31 & 31 & 34 & 33 \\
\hline Anterior end to the largest tooth tip & 7 & 8 & 7 & 9 & 8 & 9 \\
\hline Anterior end to the other teeth tips & 14 & 16 & 14 & 18 & 15 & 17 \\
\hline Anterior end to amphids & 22 & 23 & 25 & 22 & 22 & 23 \\
\hline Anterior end to excretory pores & 88 & 80 & 85 & 95 & 87 & 91 \\
\hline Anterior end to the nerve ring & 251 & 254 & 247 & 274 & 271 & 264 \\
\hline Pharynx length & 563 & 548 & 545 & 606 & 602 & 589 \\
\hline Spicule length & 44 & 42 & 41 & - & - & - \\
\hline Cloacal setae length & 8 & 7 & 7 & - & - & - \\
\hline Anterior end to the vulva & - & - & - & 2987 & 3107 & 2968 \\
\hline Body diameter at level of the vulva & - & - & - & 61 & 70 & 61 \\
\hline $\mathrm{V}(\%)$ & - & - & - & 66 & 67 & 66 \\
\hline Anal body diameter & 35 & 36 & 37 & 37 & 36 & 35 \\
\hline Tail length & 94 & 92 & 96 & 110 & 114 & 111 \\
\hline Tail length/anal body diameter & 2.7 & 2.5 & 2.6 & 3 & 3.2 & 3.1 \\
\hline
\end{tabular}

\subsubsection{Type Material}

A holotype male (MABIK NA00156666), in glycerin on an HS slide, was deposited in the nematode collection at the specimen conservation room of the Marine Biodiversity Institute of Korea (MABIK), Seochun, Korea. Two paratype males (KIOST NEM-1-1187 and KIOST NEM-1-1201) and three females (KIOST NEM-1-1211, KIOST NEM-1-1221, and KIOST NEM-1-1225), mounted on HS slides, were deposited in the nematode collection at the specimen conservation room of the Bio-Resources Bank of Marine Nematodes (BRBNM), East Sea Research Institute, Korea Institute of Ocean Science and Technology (KIOST), Korea.

\subsubsection{Type Locality and Habitat}

The locality was the subtidal zone of Dokdo Islands ( $\left.37^{\circ} 14^{\prime} 21.00^{\prime \prime} \mathrm{N}, 131^{\circ} 52^{\prime} 4.00^{\prime \prime} \mathrm{E}\right)$, Ulleung-gun, Gyeongsangbuk-do, Korea, where the specimens were collected on 22 May 2015 by H. S. Rho. The nematodes were extracted from the subtidal sediments with tiny shell gravels, and detritus was collected at a depth of $5 \mathrm{~m}$.

\subsubsection{Etymology}

This species' name, tripapillatus, comes from the Latin, meaning crested, in reference to the three pairs of papillae on the tail tip.

\subsubsection{Measurements}

See Table 1 for measurements and morphometrics. 


\subsubsection{Diagnosis}

The body is relatively long (4071-4435 $\mu \mathrm{m}$ in males and $4514-4661 \mu \mathrm{m}$ in females) and slender $(\mathrm{a}=82-88$ in males and $64-72$ in females), with a slightly constricted head, relatively long cephalic setae (10-12 $\mu \mathrm{m})$, a large buccal cavity with a thick cuticular wall and three teeth (the left subventral tooth is larger than the right subventral and dorsal teeth), two pre-cloacal supplementary spines in males, five pairs of long cloacal setae (three precloacal and two postcloacal setae in the subventral position), a ventrally arcuated conoid tail with three tail papillae and two pairs of short setae.

\subsubsection{Description}

Males: Bodies are comparatively long $(4071-4435 \mu \mathrm{m})$ and slender, slightly tapering toward both extremities (Figure 1A). Maximum body diameter at the mid body level is $49-52 \mu \mathrm{m}$. The cuticle of the body is smooth. The diameter of the head is $30 \mu \mathrm{m}$ wide, with a slight constriction posterior to the cephalic seta. The lip region has six conical lips, which are deeply separated, each bearing small rounded inner labial papillae. Six outer labial and four cephalic setae are arranged in a single circle, almost equal in size (10-12 $\mu \mathrm{m})$ (Figures 1C, 3A and 4A). The buccal cavity is large (29-31 $\mu \mathrm{m}$ long and 19-20 $\mu \mathrm{m}$ wide), with sclerotized walls and three teeth. The left subventral tooth $(22-24 \mu \mathrm{m}$ long) is larger than the right subventral and dorsal teeth, and the tip is stretched up to the cephalic setae. The amphideal fovea ( $8-11 \mu \mathrm{m}$ wide) is pocket-like, with an elliptical opening that is located 20-25 $\mu \mathrm{m}$ from the anterior end (Figures 1C and 4B). The pharynx (545-563 $\mu \mathrm{m}$ long) is cylindrical and is approximately $12-13 \%$ of total body length, with a corresponding body diameter of $42-43 \mu \mathrm{m}$. The excretory pore is situated $80-88 \mu \mathrm{m}$ from the anterior end. The nerve ring is approximately $5.7-6.1 \%$ of the total body length from the anterior end. The somatic setae are randomly distributed across the surface of the body (Figure 1B). Two opposed testes are situated to the right side of the intestine. The spicules are short and equal, slightly ventrally curved, with a pointed distal end and a cephalated proximal end. The spicules (41-44 $\mu \mathrm{m}$ long) are approximately 1.1-1.2 times of the anal body diameter (Figures $1 \mathrm{D}$ and $4 \mathrm{E}$ ). Gubernacula are absent. Five pairs of long and stout subventral setae (7-8 $\mu \mathrm{m}$ long) are located around the cloacal region, of which three pairs are situated on each side of the cloacal opening, while the other two pairs are located on both sides behind the cloacal region (Figure 1D,E and Figure 3C). A precloacal sexual protuberance is present just anterior to the cloacal opening, bearing two small cone-shaped supplementary spines situated on the cloacal protuberance (Figure 4C). The tail is $92-96 \mu \mathrm{m}$ in length, conoid, slightly curved ventrally, and approximately 2.5-2.7 times the anal body diameter (Figure 1D,E and Figure 3C). Three remarkable papillae are subventrally situated on the tail tip, of which only the anteriormost papilla consists of a pair. There are two pairs of subventral setae around the tail papillae (Figures 3D and 4D).

Females: Similar to the males in general appearance, but they differ in tail shape and sexual characteristics (Figure 2A,C and Figure 3B). The conical tail (110-114 $\mu \mathrm{m}$ long) is slightly arcuate with a blunt posterior end but without a tail papilla. The tail is 3.0-3.2 times the anal body diameter, with two pairs of short terminal setae (Figure 2D). The reproductive system is monodelphic with anterior reproductive branches, lying to the right side of the intestines. They have two intra-uterine eggs, $124-169 \mu \mathrm{m}$ in length and $56-67 \mu \mathrm{m}$ in width. The vulva is situated at $66 \%-67 \%$ of the total body length from the anterior end (Figure $2 \mathrm{~B}$ ). The demanian system is composed of one osmosium connecting the ductus entericus and the intestine, and one uvette, located at $170 \mu \mathrm{m}$ in front of anus, connecting the ductus uterinus with a main tube (Figure 2E).

\subsubsection{Differential Diagnosis and Relationships}

The genus Oncholaimus Dujardin, 1845 is the largest genus of the family Oncholaimidae Filipjev, 1916, containing about 120 species, which have thus far been described from various localities of littoral and deep-sea habitats in oceans all over the world [2,4]. They are distinguished from the other genera of the family by the presence of the largest left 
ventrosublateral tooth and relatively short spicules, with a monodelphic-prodelphic reproductive system in females [1]. After comparing and compiling the valid species of the genus Oncholaimus on the basis of the taxonomic key characteristics among the congeners, we artificially distinguished a group of 26 species with a conspicuous ventral papilla on the tail, which is the most important diagnostic characteristic of the genus, including the present new species, Oncholaimus tripapillatus sp. nov., and the following: O. aquaedulcis Schneider, 1937; O. bajulus Paramonov, 1937; O. balli Nicholas \& Stewart, 1984; O. cobbi (Kreis, 1932); O. deconincki Heyns \& Coomans, 1977; O. dimorphicus Tahseen, Siddiqi \& Mustaqim, 2016; O. domesticus (Chitwood \&Chitwood, 1938); O. hyrcanus Tchesunov, 1979; O. japonicus (Belogurov \& Belogurova, 1981); O. longispiculosus Gerlach, 1955; O. longus (Wieser, 1953); O. martini Wieser, 1959; O. menzeli Schneider, 1937; O. oxyuris Ditlevsen, 1911; O. paraoxyuris Salma, Nasira, Saima \& Shahina, 2017; O. paroxyuris Schuurmans Stekhoven, 1942; O. qingdaoensis Zhang \& Platt, 1983; O. rionegrensis Pastor de Ward et. al., 2013; O. rivalis Gagarin \& Gusakov, 2012; O. sahariensis Coomans \& Heyns, 1983; O. sidiiqii Tauheed \& Ahmad, 2016; Oncholaimus tripapillatus sp. nov.; O. vesicarius (Wieser, 1959); O. vietnamicus Gagarin \& Thanh, 2011; O. xiamenense Chen \& Guo, 2014; O. zhangi Gao \& Huang, 2016. Therefore, we herein provide a pictorial identification key and a comparison table of the diagnostic morphological characteristics for the species group with a conspicuous ventral papilla on the tail, with diagnostic characteristics also including the morphology of the anterior head region and the posterior tail region showing spicule and gubernaculum, which are generally important taxonomic key characters to discriminate closely related nematode species (Figure 5, Table 2).

Table 2. Comparison of diagnostic morphological characteristics of the species group with remarkable tail papillae within the genus Oncholaimus. Males only, morphometric values rounded (-: unknown).

\begin{tabular}{|c|c|c|c|c|c|c|c|}
\hline \multirow[b]{2}{*}{ Species } & \multicolumn{7}{|c|}{ Characters } \\
\hline & $\begin{array}{l}\text { Body Length } \\
(\mu \mathrm{m})\end{array}$ & a & $\mathbf{b}$ & c & $\begin{array}{c}\text { Buccal Cavity } \\
\text { Height }(\mu \mathrm{m})\end{array}$ & $\begin{array}{c}\text { Spicule } \\
\text { Length }(\mu \mathrm{m})\end{array}$ & $\begin{array}{l}\text { Number of } \\
\text { Tail Papillae }\end{array}$ \\
\hline O. aquaedulcis Schneider, 1937 & $2600-2900$ & $60-71$ & $7-9$ & $28-42$ & 39 & 100 & 1 \\
\hline O. bajulus Paramonov, 1937 & $3144-3676$ & $54-61$ & $7-8$ & $48-50$ & 35 & 40 & 1 \\
\hline O. balli Nicholas \& Stewart, 1984 & $1834-2314$ & $52-69$ & $7-8$ & $33-51$ & $26-28$ & $26-34$ & 1 \\
\hline O. cobbi Gerlach, 1954 & 3452 & 40 & 7 & 47 & 42 & 57 & 1 \\
\hline O. deconincki Heyns \& Coomans, 1977 & $3200-3770$ & $66-80$ & $7-9$ & $36-47$ & $32-41$ & $35-41$ & 1 \\
\hline O. dimorphicus Tahseen et. al., 2016 & 1925-2076 & $69-77$ & 6 & $48-57$ & - & $36-38$ & 1 \\
\hline O. domesticus Chitwood, 1960 & $2700-3350$ & $54-78$ & 7 & $39-47$ & $36-38$ & $51-54$ & 1 \\
\hline O. hyrcanus Tchesunov, 1976 & 2810 & 57 & 7 & 36 & 29 & 55 & 1 \\
\hline O. japonicas Belogurov \& Belogurova, 1981 & $3250-3420$ & $60-89$ & $9-10$ & $52-62$ & $26-31$ & $37-41$ & 1 \\
\hline O. longispiculosus Gerlach, 1955 & 3090 & 31 & 7 & 46 & 40 & 108 & 1 \\
\hline O. longus Wieser, 1953 & $5000-6740$ & $130-150$ & 13 & $104-108$ & 26 & 42 & 1 \\
\hline O. martini Wieser, 1959 & 3890 & 65 & 8 & 43 & 36 & 51 & 1 \\
\hline O. menzeli Schneider, 1937 & 1885-2084 & $75-83$ & 6 & $34-45$ & 22 & 30 & 1 \\
\hline O. oxyuris Gerlach, 1957 & 2970 & 62 & 7 & 42 & 32 & 45 & 1 \\
\hline O. paraoxyuris Salma et. al, 2017 & 4100 & 83 & 11 & 64 & 38 & 50 & 1 \\
\hline O. paroxyuris Schuurmans Stekhoven, 1942 & 1512 & 42 & 6 & 47 & - & - & 1 \\
\hline O. qingdaoensis Zhang \& Platt, 1983 & $2380-2640$ & $92-98$ & $6-7$ & $48-53$ & $25-27$ & $34-36$ & 1 \\
\hline O. rionegrensis Pastor de Ward et. al., 2013 & $2440-3030$ & $37-51$ & $6-7$ & $30-45$ & $26-33$ & $47-57$ & 1 \\
\hline O. rivalis Gagarin \& Gusakov, 2012 & 3730 & 57 & 8 & 47 & 35 & 53 & 1 \\
\hline O. sahariensis Coomans \& Heyns, 1983 & 3070 & 63 & 7 & 46 & 27 & 48 & 1 \\
\hline O. sidiiqii Tauheed \& Ahmad, 2016 & $2420-2820$ & $59-66$ & 6 & $39-50$ & $34-38$ & $35-40$ & 1 \\
\hline O. tripapillatus sp. nov. & $4071-4435$ & $82-86$ & $7-8$ & $42-48$ & $29-31$ & $41-44$ & 3 \\
\hline O. vesicarius Wieser, 1959 & 3650 & 52 & 8 & 72 & 32 & 38 & 2 \\
\hline O. vietnamicus Gagarin \& Thanh, 2011 & $1758-2226$ & $70-77$ & $5-7$ & $55-59$ & $26-29$ & $52-56$ & 1 \\
\hline O. xiamenense Chen \& Guo, 2014 & $2480-3020$ & $57-81$ & $6-7$ & $37-42$ & $27-32$ & $44-52$ & 1 \\
\hline O. zhangi Gao \& Huang, 2016 & $3718-3934$ & $55-62$ & 7 & $34-37$ & $33-35$ & $52-56$ & 1 \\
\hline
\end{tabular}


(a)

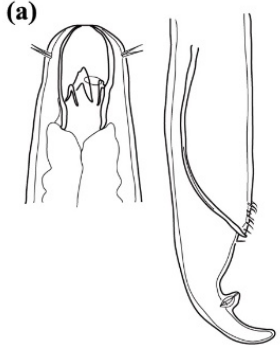

O. aquaedulcis

(d)

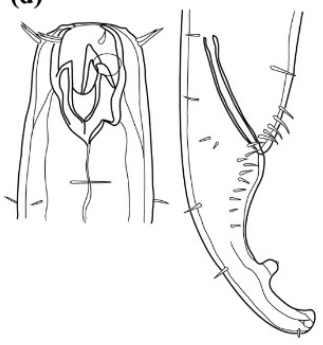

O. cobbi

(g)

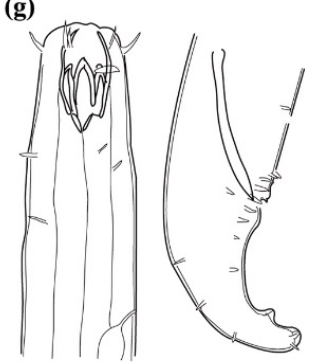

O. domesticus

(j)

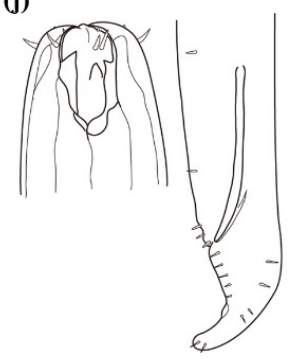

O. longispiculosus (b)

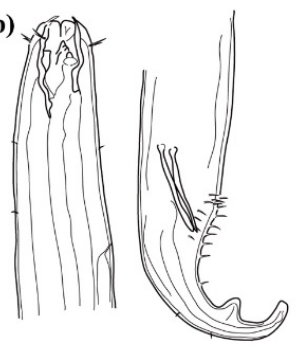

O. bajulus

(e)

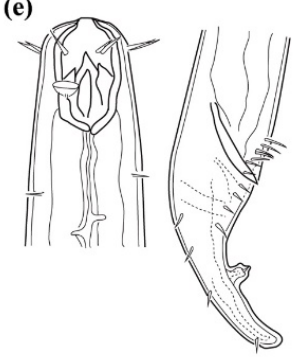

o. deconincki

(h)

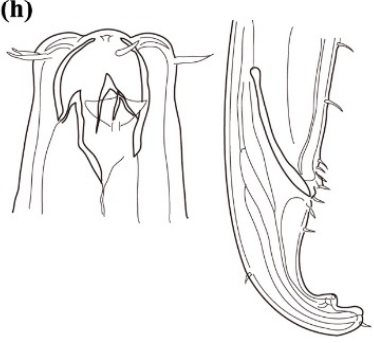

O. hyrcanus

(k)

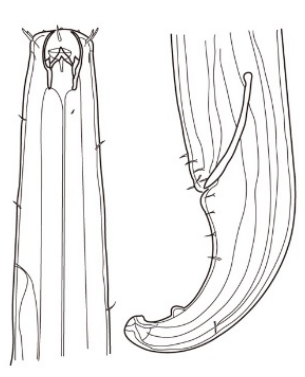

O. longus

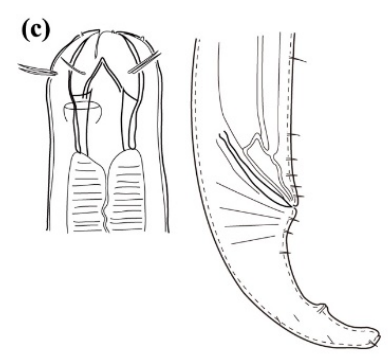

O. balli

(f)

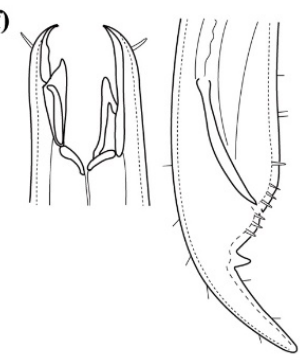

O. dimorphicus

(i)

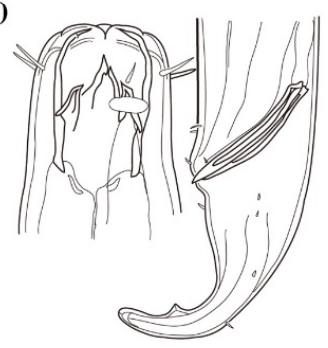

O. japonicus

(I)

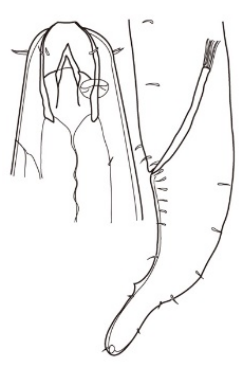

O. martini

Figure 5. Cont. 
(m)

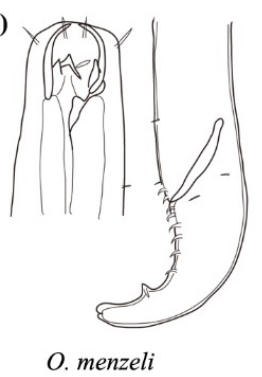

(p)

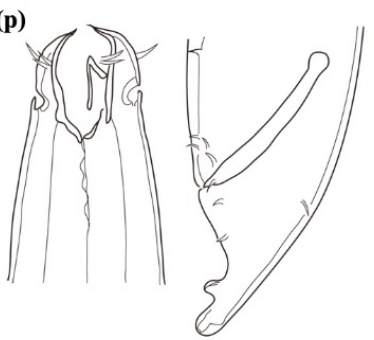

O. paroxyuris

(s)

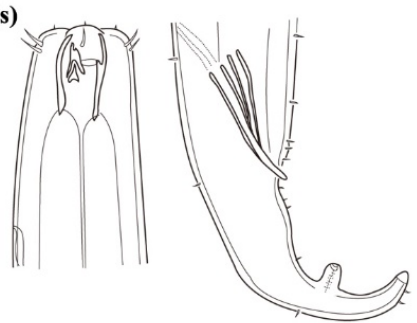

O. rivalis

(v)

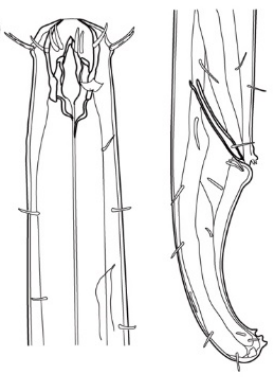

O. tripapillatus sp. nov.

(y)

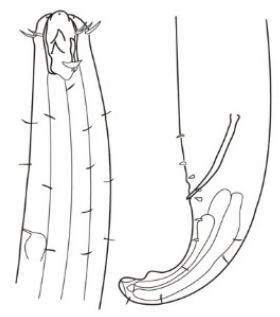

O. xiamenense

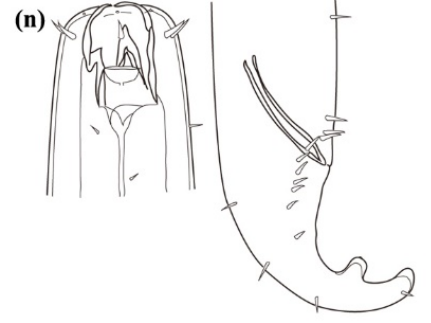

O. oxyuris

(q)
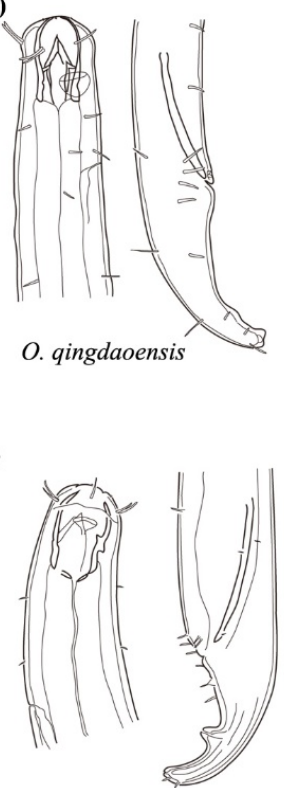

O. sahariensis

(w)

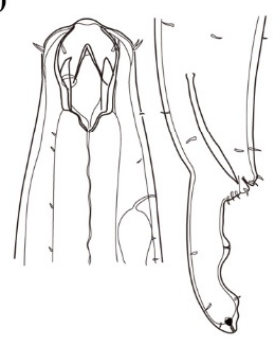

O. vesicarius

(z)

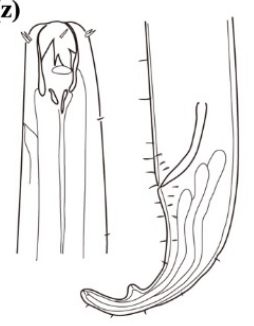

O. zhangi

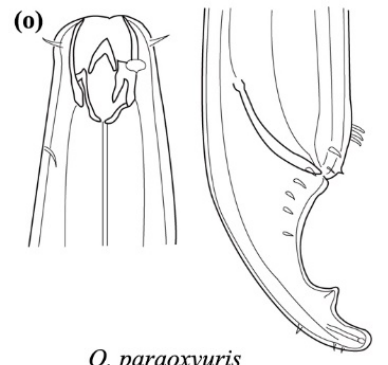

O. paraoxyuris

(r)

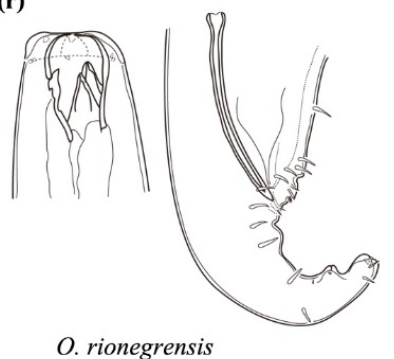

(u)

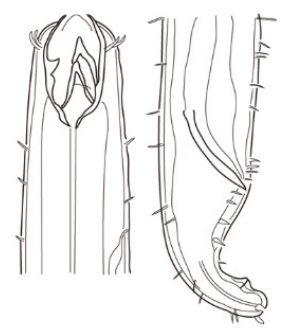

O. sidiiqii

(x)

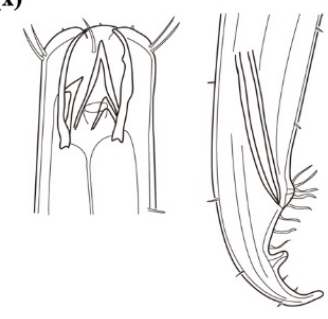

O. vietnamicus

Figure 5. Pictorial key to the species group with remarkable tail papillae of the genus Oncholaimus. Source of the figures: (a) Schneider (1937); (b) Paramonov (1937); (c) Nicholas and Stewart (1984); (d) Gerlach (1954); (e) Heyns and Coomans (1977); 
(f) Tahseen, Siddiqi and Mustaqim (2016); (g) Chitwood (1960); (h) Tchesunov (1976); (i) Belogurov and Belogurova (1981); (j) Gerlach (1955); (k) Wieser (1953); (1) Wieser (1959); (m) Schneider (1937); (n) Gerlach (1957); (o) Salma, Nasira, Saima and Shahina (2017); (p) Schuurmans Stekhoven (1942); (q) Zhang and Platt (1983); (r) Pastor de Ward et. al., (2013); (s) Gagarin and Gusakov (2012); (t) Coomans and Heyns (1983); (u) Tauheed and Ahmad (2016); (v) O. tripapillatus sp. nov.; (w) Wieser (1959); (x) Gagarin and Thanh (2011); (y) Ghen and Guo (2014); (z) Gao and Huang (2016).

Oncholaimus tripapillatus sp. nov. was discovered in the shallow subtidal coarse detritus and shell gravels collected around Dokdo Islands of the East Sea, northwest Pacific Ocean. Oncholaimus tripapillatus sp. nov. is characterized by a combination of the following features: (1) the presence of a slightly constricted head; (2) relatively long cephalic setae (10-12 $\mu \mathrm{m})$; (3) the presence of a precloacal sexual protuberance and two small, stout cone-shaped spines situated just anterior to the cloaca in males; (4) five pairs of long cloacal setae (three pairs of precloacal and two pairs of postcloacal setae in the subventral position); (5) a conoid tail, with three conspicuous papillae at the end of the tail in males; (6) the presence of two pairs of short and stout setae around the tail papillae. Among the genus Oncholaimus, there are 25 species with conspicuous ventral papillae on the tail region. Of these, only four species-i.e., O. domesticus (Chitwood \& Chitwood, 1938), O. qingdaoensis Zhang \& Platt, 1983, O. rionegrensis Pastor de Ward et al., 2013, and O. sahariensis Coomans \& Heyns, 1983-are reported to have the preanal supplementary spines in males. Oncholaimus tripapillatus sp. nov. closely resembles these four species based on the presence of a conoid tail with remarkable ventral papillae and a preanal supplementary spine in males. However, Oncholaimus tripapillatus sp. nov. differs from O. domesticus by the cloacal setae pattern (arranged in a longitudinal row of five pairs of cloacal setae rather than arranged in a transverse semicircle of 13-15 cloacal setae) and the position of the tail papillae (at the end of the tail rather than in the distal third of the tail). Oncholaimus tripapillatus sp. nov. is distinguished from $O$. sahariensis by a relatively longer body length in males (4071-4435 $\mu \mathrm{m}$ vs. $2720 \mu \mathrm{m}$ ), the number and arrangement of the cloacal setae (arranged in a longitudinal row of five pairs of cloacal setae rather than in a transverse semicircle of 16 cloacal setae), and the position of the tail papillae (at the end of tail rather than in the middle of tail). Oncholaimus tripapillatus sp. nov. is distinguished from $O$. rionegrensis by a longer body length in males $(4071-4435 \mu \mathrm{m}$ vs. $2440-3030 \mu \mathrm{m})$, a relatively shorter spicule length (41-44 $\mu \mathrm{m}$ vs. $47-57 \mu \mathrm{m})$, the number of cloacal setae (five pairs vs. nine pairs), the number of tail papillae (three vs. one), and the height of the tail papillae $(2.4-2.7 \mu \mathrm{m}$ vs. $7 \mu \mathrm{m})$. Oncholaimus tripapillatus sp. nov. also resembles $O$. qingdaoensis in possessing a constricted head, relatively long cephalic setae, longitudinally arranged cloacal setae in a row, and the presence of preanal supplementary spines in males. However, Oncholaimus tripapillatus sp. nov. differs from O. qingdaoensis in body length in males (4071-4435 $\mu \mathrm{m}$ vs. $2350-2640 \mu \mathrm{m})$ and the number of tail papillae (three vs. one). Moreover, Oncholaimus tripapillatus sp. nov. has a precloacal sexual protuberance situated just anterior to the cloaca opening; this feature is not shared by O. qingdaoensis.

\subsection{Description of Oncholaimus Qingdaoensis Zhang \& Platt, 1983}

Class Enoplea Inglis, 1983

Order Enoplida Filipjev, 1929

Family Oncholaimidae Filipjev, 1916

Genus Oncholaimus Dujardin, 1845

Oncholaimus qingdaoensis Zhang \& Platt, 1983 (Figures 6-8, Table 3) 


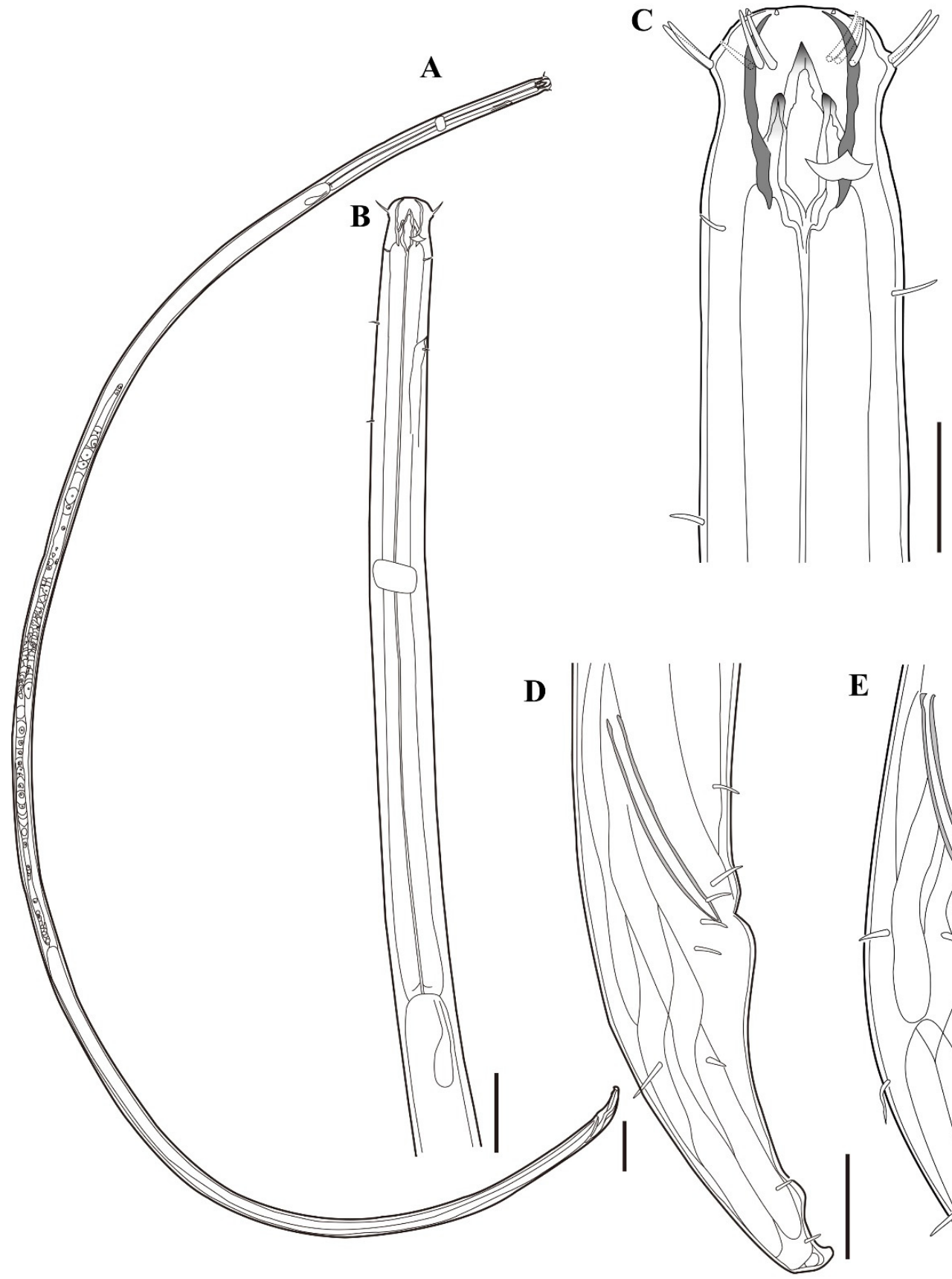




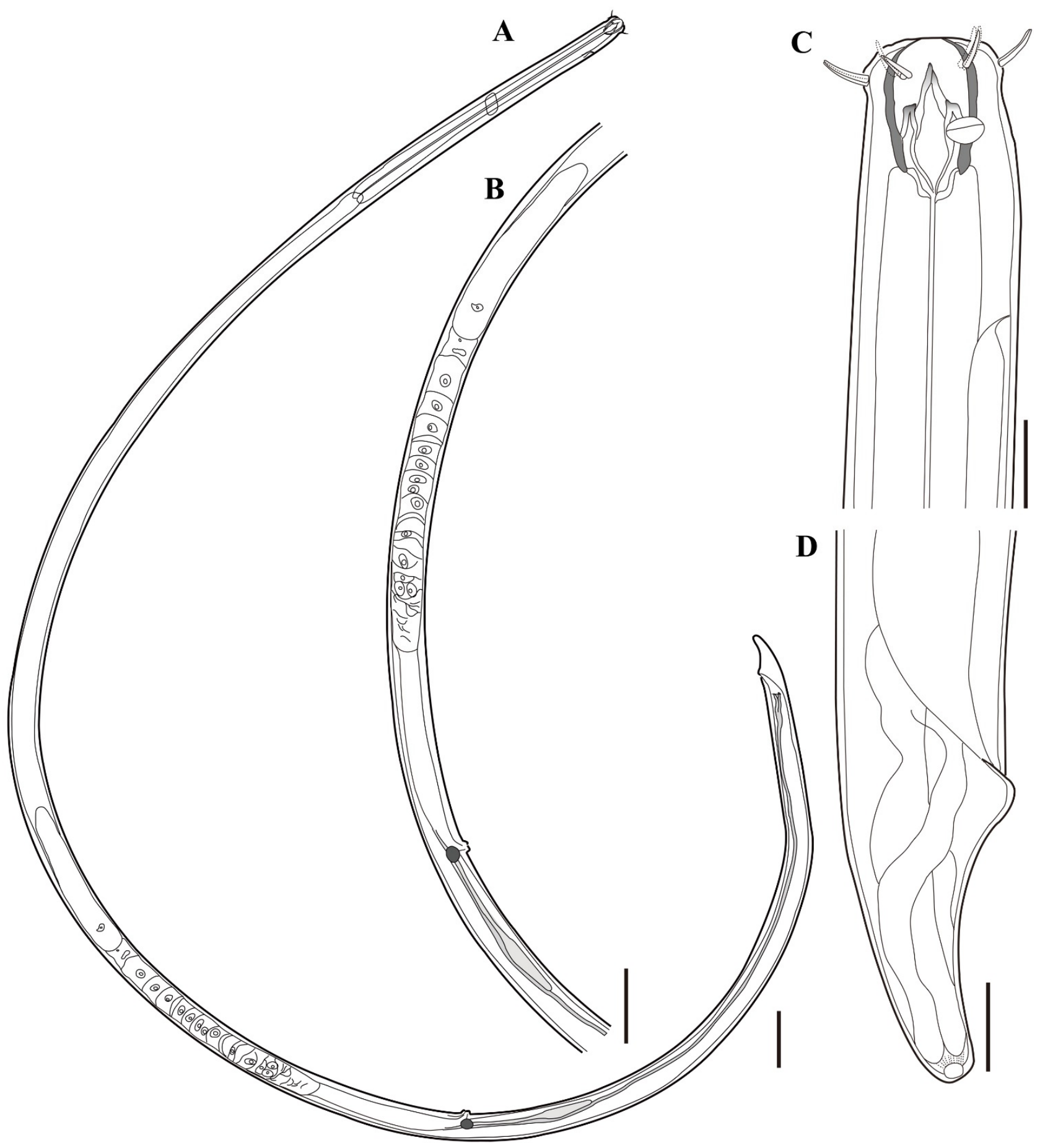

Figure 7. Oncholaimus qingdaoensis Zhang \& Platt, 1983-lateral view of a female: (A) habitus; (B) vulva region and demanian system; (C) head region; (D) tail region (scale bars: $(\mathbf{A}, \mathbf{B})=100 \mu \mathrm{m} ;(\mathbf{C}, \mathbf{D})=20 \mu \mathrm{m})$. 

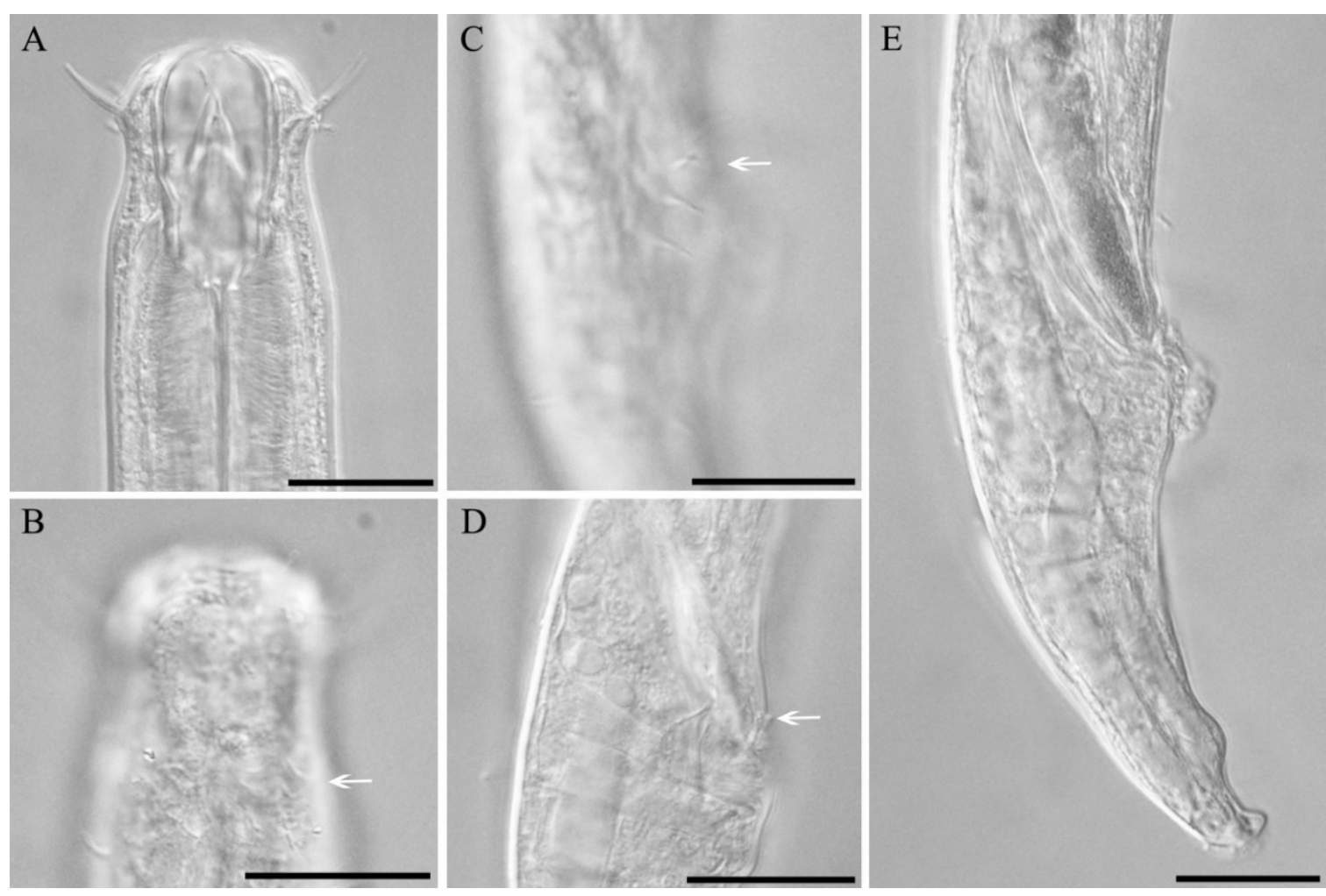

Figure 8. Oncholaimus qingdaoensis Zhang \& Platt, 1983-DIC photomicrographs, showing the lateral view of a male: (A) head region; (B) head region showing amphideal fovea (arrow); (C) ventral cloacal seta (arrow); (D) cloacal region showing precloacal spins (arrow); (E) spicules and tail region (scale bars: $(\mathbf{A}-\mathbf{E})=20 \mu \mathrm{m})$.

Table 3. Morphometrics of Oncholaimus qingdaoensis (in $\mu \mathrm{m}$ ).

\begin{tabular}{|c|c|c|c|c|c|}
\hline Characters & $10^{7}$ & $2 \sigma^{7}$ & $30^{7}$ & 1 우 & 29 \\
\hline Body length & 3379 & 3505 & 3715 & 4061 & 3550 \\
\hline a & 82 & 86 & 85 & 75 & 67 \\
\hline $\mathrm{b}$ & 7 & 7 & 7 & 7 & 7 \\
\hline c & 46 & 45 & 44 & 56 & 43 \\
\hline $\begin{array}{l}\text { Head diameter at the level of cephalic } \\
\text { setae }\end{array}$ & 28 & 29 & 29 & 32 & 31 \\
\hline Body diameter at the level of the cardia & 36 & 40 & 38 & 44 & 47 \\
\hline Maximum body diameter & 41 & 41 & 44 & 54 & 53 \\
\hline Cephalic setae length & 10 & 12 & 11 & 11 & 11 \\
\hline Amphideal fovea diameter & 10 & 12 & 11 & 10 & 12 \\
\hline Amphideal fovea length & 5 & 6 & 7 & 5 & 7 \\
\hline Buccal cavity diameter & 17 & 19 & 18 & 17 & 21 \\
\hline Buccal cavity length & 32 & 31 & 33 & 35 & 34 \\
\hline Anterior end to the largest tooth tip & 5 & 5 & 7 & 6 & 8 \\
\hline Anterior end to the other teeth tips & 13 & 12 & 13 & 12 & 14 \\
\hline Anterior end to amphids & 22 & 20 & 23 & 22 & 22 \\
\hline Anterior end to excretory pores & 84 & 79 & 77 & 68 & 81 \\
\hline Anterior end to the nerve ring & 229 & 241 & 243 & 265 & 247 \\
\hline Pharynx length & 492 & 533 & 555 & 560 & 514 \\
\hline Spicule length & 47 & 50 & 52 & - & - \\
\hline Cloacal setae length & 8 & 8 & 8 & - & - \\
\hline Anterior end to the vulva & - & - & - & 2812 & 2990 \\
\hline Body diameter at level of the vulva & - & - & - & 54 & 56 \\
\hline $\mathrm{V}(\%)$ & - & - & - & 69 & 84 \\
\hline Anal body diameter & 30 & 29 & 32 & 38 & 40 \\
\hline Tail length & 74 & 79 & 85 & 72 & 83 \\
\hline Tail length/anal body diameter & 2.5 & 2.7 & 2.7 & 1.9 & 2.1 \\
\hline
\end{tabular}




\subsubsection{Material Examined}

The examined material included three males (MABIK NA00156663, KIOST NEM-12565, and KIOST NEM-1-2604) and two females (KIOST NEM-1-1719 and KIOST NEM-12605), mounted in anhydrous glycerin between two coverslips on an HS slide, sealed with nail polish. One male specimen (MABIK NA00156663) was deposited in the nematode collection at the specimen conservation room of the Marine Biodiversity Institute of Korea (MABIK), and the other specimens were deposited in the Bio-Resources Bank of Marine Nematodes (BRBMN), Korea Institute of Ocean Science and Technology.

\subsubsection{Locality and Habitats}

One male (MABIK NA00156663) and one female (KIOST NEM-1-1719) were collected from the intertidal sandy sediments of Namildae beach $\left(34^{\circ} 55^{\prime} 34.34^{\prime \prime} \mathrm{N}, 128^{\circ} 05^{\prime} 43.11^{\prime \prime} \mathrm{E}\right)$, Sacheon-si, Gyeongsangnam-do on 19 January 2017 by H. Lee and H. J. Lee. Two males (KIOST NEM-1-2565 and KIOST NEM-1-2604) and one female (KIOST NEM-1-2605) were collected from the intertidal sandy sediments of Ujeon beach $\left(34^{\circ} 58^{\prime} 18.00^{\prime \prime} \mathrm{N}, 126^{\circ} 08^{\prime} 11.00^{\prime \prime}\right.$ E), Sinan-gun, Jeollanam-do on 26 May 2020 by H. Lee and H. S. Rho.

\subsubsection{Measurements}

See Table 3 for measurements and morphometrics.

\subsubsection{Description}

Males: Bodies are comparatively long (3379-3715 $\mu \mathrm{m})$ and slender, typically cylindrical in appearance (Figure 6A). The maximum body diameter at the mid body level is $41-44 \mu \mathrm{m}$. The head is constricted immediately posterior to the cephalic setae (Figures 6C and 8A). The head region (28-29 $\mu \mathrm{m}$ in width) has typically six rounded lips, slightly attenuated toward the end, with a minute rounded inner labial papilla. Six outer labial and four cephalic setae are arranged in one circle, almost equal in size $(10-12 \mu \mathrm{m})$, inserted at the level of the amphideal fovea. The buccal cavity (31-33 $\mu \mathrm{m}$ deep, $17-19 \mu \mathrm{m}$ wide) has a thick cuticular wall and three well-developed teeth. The left subventral tooth is the largest $(26-28 \mu \mathrm{m})$, with its tip stretched up to the cephalic setae, while the right subventral and dorsal teeth are almost equal in size $(19-21 \mu \mathrm{m})$. The amphideal fovea is pocket-like, $10-12 \mu \mathrm{m}$ in width (corresponding head diameter of 37\%-41\%), and 5-7 $\mu \mathrm{m}$ in height, located $20-23 \mu \mathrm{m}$ from the anterior end (Figures 6C and 8B). The pharynx (492-555 $\mu \mathrm{m}$ long) is cylindrical, approximately $15 \%$ of the total body length, with a corresponding body diameter of $36-40 \mu \mathrm{m}$. The excretory pore is situated $77-84 \mu \mathrm{m}$ from the anterior end. The nerve ring is situated $229-243 \mu \mathrm{m}$ from the anterior end, with a corresponding body diameter of $35-38 \mu \mathrm{m}$, and $44 \%-47 \%$ of the length of the pharynx (Figure $6 \mathrm{~B}$ ). The somatic setae are sparsely distributed on the surface across the body. Two opposed testes are located on the right side of the intestine. The spicules are short and straight (47-52 $\mu \mathrm{m}$ long), proximally cephalated and pointed distally (Figure 6D,E and Figure 8E). The gubernacula are absent. Four pairs of long and stout setae are located in the cloacal region in a row (Figures 6D,E and 8C). Two unapparent pairs of precloacal spines are situated at the cloacal opening (Figures $6 \mathrm{E}$ and $8 \mathrm{D}$ ). The tail is $74-85 \mu \mathrm{m}$ long, approximately $2.5-2.7$ times the anal body diameter. A conspicuous ventral tail papilla is situated approximately $14-16 \mu \mathrm{m}$ from the tail tip (Figure $6 \mathrm{D}, \mathrm{E}$ and Figure $8 \mathrm{E}$ ). Two pairs of ventral setae $(3-4 \mu \mathrm{m})$ are situated in the tail papilla.

Females: Very similar to the males but differ in several dimensions, tail shape, and sexual characteristics. The body is 3550-4061 $\mu \mathrm{m}$ long, with a maximum body diameter of 53-54 $\mu \mathrm{m}$ (Figure $7 \mathrm{~A}, \mathrm{C}$ ). The conical tail (72-83 $\mu \mathrm{m}$ long) is slightly curved ventrally, without a ventral papilla (Figure 7D), and approximately 1.9-2.1 times the anal body diameter. The reproductive system is monodelphic with anterior reproductive branches, lying to the right side of the intestines. The vulva is situated at $69-84 \%$ of the total body length from the anterior end (Figure 7B). The demanian system is composed of one 
osmosium connecting the ductus entericus and the intestine, and one uvette, located at $870 \mu \mathrm{m}$ in front of the anus, connecting the ductus uterinus with a main tube (Figure 7B).

\subsubsection{Distribution}

China (Qingdao), Korea (Sacheon, Sinan).

\subsubsection{Differential Diagnosis and Relationships}

Oncholaimus qingdaoensis Zhang \& Platt, 1983 was first described from intertidal sand in Qingdao, China. Oncholaimus qingdaoensis has been previously reported only in that type of locality. The present Korean specimens of Oncholaimus qingdaoensis were discovered from the intertidal sandy sediments of the southern and western coasts of Korea. Oncholaimus qingdaoensis is easily distinguished from its congeners as having the following characteristic combinations: (1) the presence of a constricted head, (2) relatively long cephalic setae, (3) the presence of four pairs of long and stout cloacal setae longitudinally arranged in a row in males, (4) the presence of two pairs of precloacal spines in males, and (5) a conoid tail with conspicuous ventral papillae in front of the tail tip in males. The present Korean specimens of $O$. qingdaoensis resemble O. domesticus (Chitwood \& Chitwood, 1938), $O$. hyrcanus Tchesunov, 1979, O. longus (Wieser, 1953), and O. xiamenense Chen \& Guo, 2014, mainly in possessing a conoid tail with conspicuous ventral papillae in front of the tail tip in males. The present Korean specimens of O. qingdaoensis are clearly distinguished from $O$. domesticus and O. hyrcanus by the absence of a precloacal sexual protuberance in males and by a cloacal setae pattern (longitudinally arranged in a row of cloacal setae rather than arranged in a transverse semicircle of cloacal setae). The Korean specimens differ from O. longus in terms of body length (3.4-3.7 mm vs. 5-6.7 $\mathrm{mm}$ in males), number of cloacal setae (four pairs vs. seven pairs), and by possessing two pairs of cloacal spinae (absent in O. longus). Moreover, the Korean specimens are also distinguished from O. xiamenense based on the body length (3.4-3.7 mm vs. 2.5-3 mm in males), number of cloacal setae (four pairs vs. six pairs), and the presence of a constricted head and precloacal spins (absent in the original description of $O$. xiamenense). The present Korean specimens agree well with Zhang and Platt's (1983) original description in general features, especially for a constricted head, the detailed shape of the tail, and the number and shape of cloacal setae. However, the Korean specimens differ from the Chinese specimens in the longer body length in males

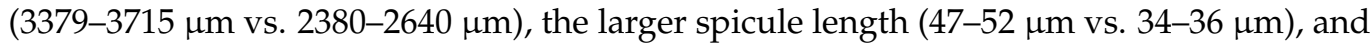
the presence of ventral tail papillae situated approximately 14-16 $\mu \mathrm{m}$ from the tail tip.

Author Contributions: Conceptualization, data curation, writing-original draft preparation, and writing-review and editing, H.L. (Hyojin Lee) and H.R.; investigation, H.L. (Heegab Lee) and H.R.; funding acquisition, H.R. All authors have read and agreed to the published version of the manuscript.

Funding: This research was supported by a grant from the National Marine Biodiversity Institute of Korea (2021M01100) and by the research projects of the Korea Institute of Ocean Science and Technology (PG52510, PE99913).

Institutional Review Board Statement: Not applicable.

Informed Consent Statement: Not applicable.

Data Availability Statement: Not applicable.

Conflicts of Interest: The authors declare no conflict of interest.

\section{References}

1. Smol, N.; Muthumbi, A.; Sharma, J. Handbook of Zoology. Gastrotricha, Cycloneuralia and Gnathifera; Nematoda. 7.3 Order Enoplida; Walter De Gruyter: Berlin, Germany, 2013; Volume 2.

2. Gerlach, S.; Riemann, F. The Bremerhaven Checklist of Aquatic Nematodes. A Catalogue of Nematoda Adenophorea excluding the Dorylaimida. Veröffentlichungen Inst. Meeresforsch. Bremerhav. Suppl. 1974, 4, 405-736. 
3. Zeppilli, D.; Bellec, L.; Cambon-Bonavita, M.-A.; Decraemer, W.; Fontaneto, D.; Fuchs, S.; Gayet, N.; Mandon, P.; Michel, L.N.; Portail, M.; et al. Ecology and trophic role of Oncholaimus dyvae sp. nov.(Nematoda: Oncholaimidae) from the lucky strike hydrothermal vent field (Mid-Atlantic Ridge). BMC Zool. 2019, 4, 1-15. [CrossRef]

4. Shimada, D.; Suzuki, A.C.; Tsujimoto, M.; Imura, S.; Kakui, K. Oncholaimus langhovdensis sp. nov.(Nematoda: Enoplea: Oncholaimida), a new species of free-living marine nematode from Langhovde, Dronning Maud Land, East Antarctica. Species Divers. 2017, 22, 151-159. [CrossRef]

5. Belogurov, O.; Belogurova, L.; Pavlyuk, O. Morphology and systematic position of two new species of marine nematodes (Nematoda: Oncholaimidae) from Far-Eastern seas: Oncholaimium olium sp. n. and Pseudoncholaimus vesicarius (Wieser, 1959) comb. nov. Biol. Morya 1975, 2, 25-30.

6. Belogurov, O.; Belogurova, L. Morphology of Oncholaimus paropisthonchus sp. n., Oncholaimus zinus sp. n., Oncholimium unicum sp. n. and key for genera of the subfamily Oncholaiminae(Nematoda). Zool. Zhurnal 1978, 57, 977-986.

7. Belogurov, O.; Belogurova, L.; Pavlyuk, O. Three new species of free-living nematodes from the family Oncholaimidae from the Far-Eastern seas of the USSR, and a differential key for Pseudoncholaimus species. In Coastal Plankton and Benthos of the Northern Parts of the Sea of Japan; Akademiya Nauk SSSR, Dal'nevostochnyı̆ Nauchnyı̆ Tsentr; Institut Biologii Morya: Vladivostok, Russia, 1980; pp. 57-64.

8. Smolyanko, O.; Belogyrov, O. On the study of the morphology and taxonomy on two nematode species of the genus Oncholaimium (Nematoda, Oncholaimidae) and comments on the independence of this genus and on synonymy of O. olium and O. sinensis. Zool. Zhurnal 1991, 70, 17-24.

9. Wieser, W. A collection of marine nematodes from Japan. Publ. Seto Mar. Biol. Lab. 1955, 4, 159-181. [CrossRef]

10. Shimada, D.; Kajihara, H.; Mawatari, S.F. Three new species of free-living marine nematodes (Nematoda: Enoplida) from northern Japan. Species Divers. 2009, 14, 137-150. [CrossRef]

11. Zhang, Z.; Platt, H.M. New species of marine nematodes from Qingdao, China. Bull. Br. Mus. Nat. Hist. Zool. 1983, 45, $253-561$. [CrossRef]

12. Chen, Y.; Guo, Y. Three new species of free-living marine nematodes from East China Sea. Zootaxa 2014, 3841, 117-126. [CrossRef] [PubMed]

13. Gao, Q.; Huang, Y. Oncholaimus zhangi sp. nov.(Oncholaimidae, Nematoda) from the intertidal zone of the East China Sea. Chin. J. Oceanol. Limnol. 2017, 35, 1212-1217. [CrossRef]

14. Lee, H.J.; Rho, H.S.; Jung, J. New Record of the Genus Oncholaimus Nematode Species (Nematoda: Oncholaimidae) from the East Sea of Korea. Korean J. Environ. Biol. 2015, 33, 170-176. [CrossRef]

15. Kristensen, R.M.; Higgins, R.P. Marine Tardigrada from the southeastern United States coastal waters I. Paradoxipus orzeliscoides n. gen., n. sp.(Arthrotardigrada: Halechiniscidae). Trans. Am. Microsc. Soc. 1989, 262-282. [CrossRef]

16. Shirayama, Y.; Kaku, T.; Higgins, R.P. Double-sided microscopic observation of meiofauna using an HS-slide. Benthos Res. 1993, 44, 41-44. [CrossRef] 